ISSN (print): 1698-6180. ISSN (online): 1886-7995

www.ucm.es/info/estratig/journal.htm

Journal of Iberian Geology 38 (1) 2012: 145-160

http://dx.doi.org/10.5209/rev_JIGE.2012.v38.n1.39210

\title{
A review on Quaternary tectonic and nontectonic faults in the central sector of the Iberian Chain, NE Spain
}

\author{
Fallas cuaternarias tectónicas y gravitacionales en el sector central de la \\ Cordillera Ibérica, NE de España
}

\author{
F. Gutiérrez*1, F.J. Gracia ${ }^{2}$, M. Gutiérrez ${ }^{1}$, P. Lucha ${ }^{1}$, J. Guerrero ${ }^{3}$, D. Carbonel ${ }^{1}$, J.P. Galve ${ }^{4}$ \\ ${ }^{1}$ Departamento de Ciencias de la Tierra, Universidad de Zaragoza, Spain \\ ${ }^{2}$ Departamento de Ciencias de la Tierra, Universidad de Cádiz,, Spain \\ ${ }^{3}$ Department of Geology and Geophysics, Utah State University, USA \\ ${ }^{4}$ Dipartimento di Scienze della Terra, Università di Modena e Reggio Emilia, Italy
}

*Corresponding author:fgutier@unizar.es

Received: 09/06/2011/ Accepted: 31/01/2012

\begin{abstract}
Several grabens superimposed on the previous contractional structures have been developed in the central sector of the Iberian Chain during the post-orogenic stage. Teruel and Calatayud grabens were formed in a first rifting phase (Miocene-Lower Pliocene). The second extensional phase is recorded by Late Pliocene-Quaternary grabens superimposed and/or inset with respect to the previous basins (Río Grío, Munébrega, Daroca and Jiloca depressions). This article reviews the existing knowledge on the main Quaternary faults (distribution, seismogenic potential) in the study area and discusses its limitations: (1) Two new grabens (Río Grío and Munébrega) have been recently documented on the basis of geomorphological mapping, suggesting that our knowledge on the distribution of Quaternary faults in the Iberian Chain is still limited. (2) Available data on cumulative displacement and long-term slip rate is scarce for a number of faults mainly due to the lack of correlatable markers on both sides of the faults and/or lack of numerical dates. (3) Our capability to estimate earthquake recurrence and elapsed time is largely limited due to the scarcity of paleoseismological data. Only the Munébrega W Fault and the Concud-Teruel Fault have been studied. The paleoearthquake record inferred for the former is probably under-represented and the latter fault has received different interpretations. The paper also includes the main results of a trenching investigation carried out in a graben generated by interstratal dissolution of evaporites, which allowed us to propose some criteria that may help to differentiate between tectonic (seismogenic) and gravitational (nonseismogenic) faults.
\end{abstract}

Keywords: geomorphological mapping, trenching, paleoseismology, gravitational deformation 


\section{Resumen}

Durante la etapa post-orogénica, en el sector central de la Cordillera Ibérica se han desarrollado varias fosas superpuestas a las estructuras compresivas previas. En la primera fase de rifting se formaron las fosas de Calatayud y Teruel (Mioceno-Plioceno inferior). La segunda fase extensional (Plioceno superior-Cuaternario) queda registrada mediante fosas superpuestas y/o encajadas a las cuencas preexistentes (depresiones del Río Grío, Munébrega, Daroca y Jiloca). Este trabajo revisa el conocimiento existente sobre las principales fallas cuaternarias (distribución, potencial sismogénico) en el área de estudio y discute sus limitaciones: (1) Recientemente se han documentado dos nuevas fosas (Río Grío, Munébrega) mediante cartografías geomorfológicas, lo que sugiere que el conocimiento sobre la distribución de fallas cuaternarias en la Cordillera Ibérica es todavía limitado. (2) Los datos disponibles relativos al desplazamiento acumulado y a tasas de desplazamiento a largo plazo son insuficientes para buena parte de las fallas, en gran medida debido a la falta de marcadores correlacionables y edades numéricas. (3) Nuestra capacidad para estimar intervalos de recurrencia y tiempo transcurrido desde el último evento está limitada por la escasez de información paleosismológica. Solamente se han estudiado las fallas de Munébrega W y Concud-Teruel. El registro de paleoterremotos inferido para la primera es probablemente incompleto y la segunda ha recibido diferentes interpretaciones. El trabajo también incluye los principales resultados de la investigación llevada a cabo mediante trincheras en una fosa generada por la karstificación interestratal de evaporitas, los cuales nos han permitido proponer algunos criterios que podrían ayudar a diferenciar entre fallas tectónicas (sismogénicas) y gravitacionales (nosismogénicas).

Palabras clave: cartografía geomorfológica, trincheras, paleosismología, deformación gravitacional.

\section{Introduction}

The Iberian Chain is an intraplate Alpine orogene with a prevailing NW-SE structural grain generated by the tectonic inversion of Mesozoic extensional basins from late Cretaceous to Early-Middle Miocene times. During the post-orogenic stage several grabens superimposed on the previous compressional structures were created. Although an extensional regime associated with the formation of the offshore Valencia Trough (Roca and Guimerà, 1992; Anadón and Roca, 1996) has prevailed in the central sector of the Iberian Chain from the Middle Miocene up to the present-day, two main phases of graben development are differentiated (Capote et al., 2002; Gutiérrez et al., 2008 and references therein). The first extensional phase formed the Teruel and Calatayud grabens, both around $100 \mathrm{~km}$ long and filled with Middle Miocene to Pliocene continental sediments several hundred meters thick, typically capped by Late Miocene or Pliocene limestones (Fig. 1). Locally, the top of these lake deposits matches altitudinally with planation surfaces cut-across pre-Neogene folded formations at the margins of the basins, constituting excellent morphostratigraphic makers for identifying recent deformation structures and assessing their activity (e.g. Gutiérrez and Gracia, 1997). A discussion on these planation surfaces may be found in Ollier et al. (2006). Some authors indicate that the Calatayud and Teruel basins were developed under a compressional regime during the early stages (e.g. Julivert, 1954; Cortés and Casas, 2000). The second extensional phase started in the Late Pliocene, generating new grabens superimposed to or inset with respect to the Calatayud and Teruel grabens and rejuvenating the latter basins. Traditionally, the Daroca Half-graben (Gracia, 1992a) and the Jiloca Depression (Gracia et al., 2003; Rubio and Simón, 2007 and references therein) were attributed to this rifting phase. Recently, additional PlioQuaternary grabens have been documented for the first time by means of geomorphological mapping; the Río Grío Graben (Gutiérrez et al., 2009a) and the Munébrega Half-graben (Gutiérrez, 1998; Gutiérrez et al., 2009b) (Fig. 1). Additional advances carried out in the last few years include: (1) Constraining the timing of the activity of some Quaternary faults by numerical dating and calculating slip rates. (2) Analysis of the paleoseismological record associated with two Quaternary faults (Munébrega W Fault and Concud-Teruel Fault) using artificial exposures and trenches. (3) Investigation of nontectonic normal faults related to interstratal dissolution of evaporites, proposing criteria to differentiate between tectonic and gravitational faults. This paper reviews the existing knowledge on the main Quaternary faults in the central sector of the Iberian Range, embracing an area from the Munébrega Half-graben to the Jiloca Depression. It also presents some ideas for possible future investigations that may help to improve the seismic characterization of the active faults taking into consideration their relationships with the associated Quaternary landforms and deposits.

\section{The Río Grío Graben}

The Río Grío valley, located to the NE of Calatayud Neogene Graben (Fig. 1) and traditionally regarded as an erosional fluvial valley, was recently interpreted as a neotectonic graben on the basis of detailed geomorphological mapping (Gutiérrez et al., 2009a). This $27 \mathrm{~km}$ long and NW-SE trending depression is filled by deeply dissected alluvial fan deposits and flanked by prominent 
Fig. 1.- Sketch showing the distribution of the Plio-Quaternary tectonic depressions in the central sector of the Iberian Chain.

Fig. 1.- Distribución de las depresiones tectónicas Plio-cuaternarias en el sector central de la Cordillera Ibérica.

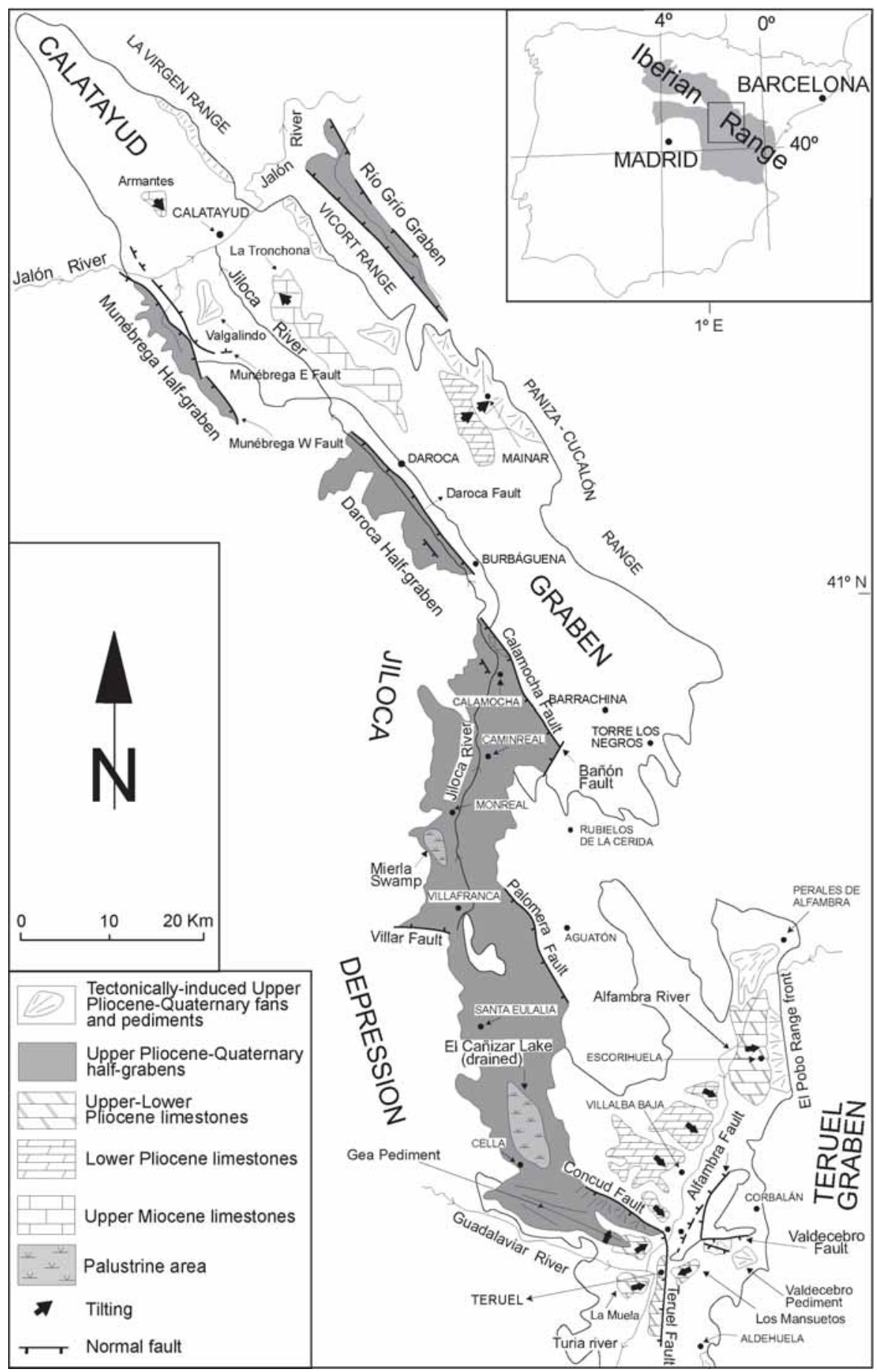

ranges made up of resistant Paleozoic rocks of the $\mathrm{Ca}$ latayud-Montalbán Massif, the Vicort-Modorra Range to the SW and the Algairén Range to the NE (Fig. 2). The Vicort-Modorra Range constitutes an uplifted horst that separates the Calatayud and the Río Grío graben. This depression has a markedly asymmetric geometry. The southwestern margin is controlled by two rectilinear and well-defined NW-SE master normal faults: the 15.5 $\mathrm{km}$ long Vicort Fault and the $5.9 \mathrm{~km}$ long Modorra Fault (Table 1). Both the Vicort and Modorra faults juxtapose Paleozoic rocks against Plio-Quaternary alluvial fan de- posits (Fig. 2A) and control linear mountain fronts with triangular facets up to 230 and $140 \mathrm{~m}$ high, respectively. These two faults are separated in Codos village area by a gap with a traverse tectonic depression bounded by NNESSW- and NE-SW-trending cross-faults and drained by the Güemil Stream (Fig. 2). The northeastern margin of the Río Grío depression is controlled by a series of shorter faults with less obvious geomorphic expression. The anomalous oblique orientation of some drainages in the NE margin of the depression seems to be controlled by uplifted (Horcajo Stream) or backtilted fault blocks 


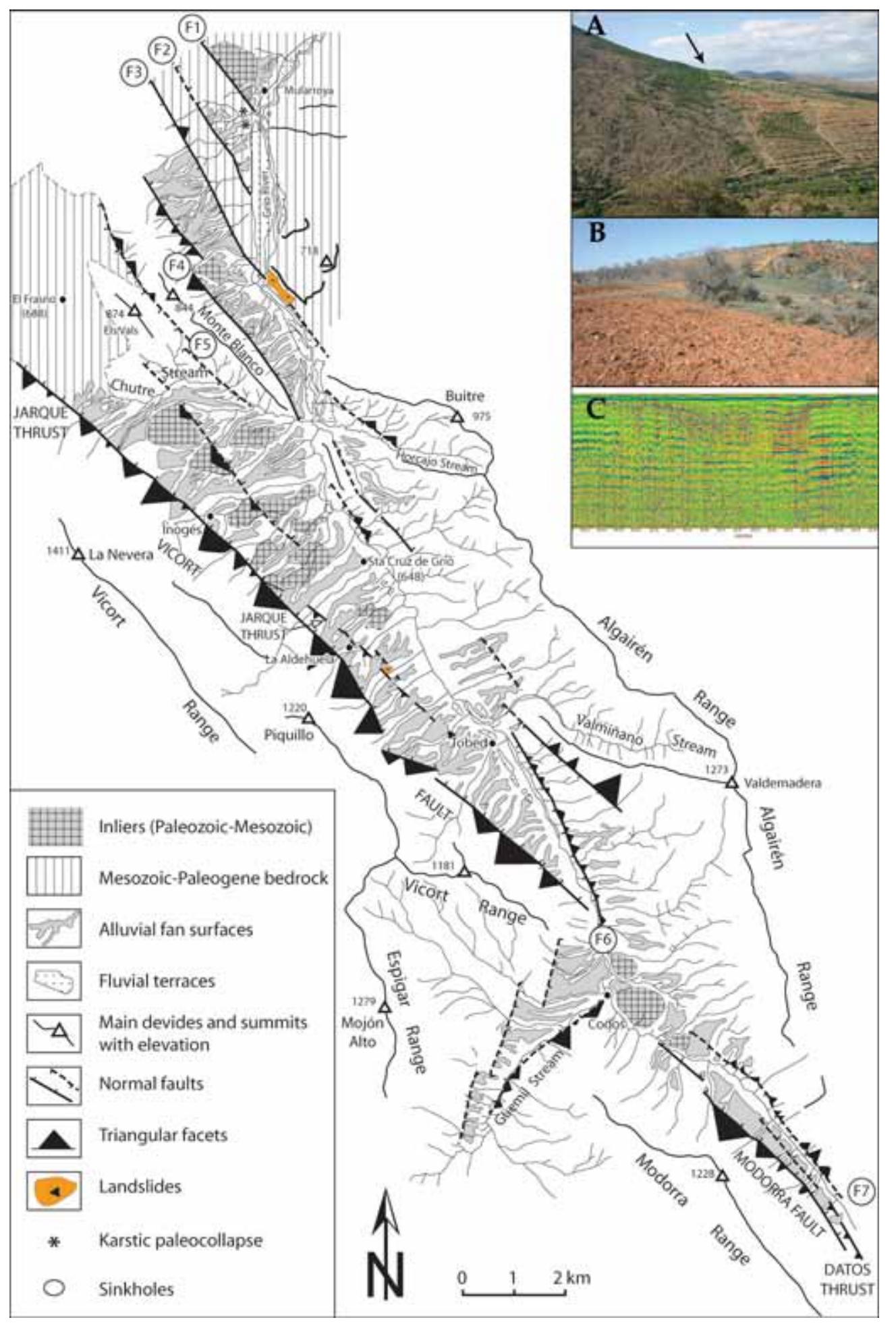

Fig. 2.- Geomorphological map of the Río Grío Graben. A: Vicort Fault, juxtaposing Paleozoic rocks against Pio-Quaternary alluvial fan deposits of the graben fill. B: Downhillfacing scarp on alluvial fan surface offset by fault F7. C: GPR profile acquired across an uphill-facing scarp produced by an antithetic fault SE of La Aldehuela.

Fig. 2.- Mapa geomorfológico de la Fosa del Río Grío. A: Falla de Vicort poniendo en contacto rocas Paleozoicas y depósitos Plio-cuaternarios de abanico alluvial. B: Escarpe orientado ladera abajo en la superficie de un abanico aluvial desplazado por la falla F7. C: Perfil de georadar tomado perpendicularmente a un escarpe orientado ladera arriba producido por una falla antitética al SE de La Aldehuela.

(Valmiñano Stream) in combination with step overs. In the northern sector of the morpho-structural depression, the Paleozoic rocks are overlain unconformably by Mesozoic and Paleogene formations in two extensive outcrops. Here, the graben shows a more complex structure composed of a sequence of horsts and grabens around 1 $\mathrm{km}$ wide controlled by NW-SE-striking faults with an en echelon right-stepping arrangement. These faults truncate alluvial fan deposits in their proximal (F1, F2, F4) or distal (F3) sectors. Southwest of Mularroya an outcrop exposes fault $\mathrm{F} 1$ juxtaposing alluvial fan deposits against Mesozoic rocks.

The Río Grío depression is largely occupied by alluvial fan deposits overlying a very irregular paleorelief and locally interrupted by inliers of Paleozoic and Mesozoic rocks (Fig. 2A). The deeply dissected alluvial fill is typically more than $30 \mathrm{~m}$ thick and reaches the highest thickness $(>90 \mathrm{~m})$ in the central sector of the depression 
(Tobed area). Based on the relative height of the fan surfaces and the regional paleogeographic evolution, we ascribe a Plio-Quaternary age for the basin fill. The alluvial fan deposits and surfaces are locally offset by intrabasinal faults. The faults dipping towards the valley produce downhill-facing scarps, whereas those with opposite dip are expressed as antislope scarps. Fault F7 has displaced a fan surface on its NW sector forming a downhill-facing scarp around $37 \mathrm{~m}$ high (Fig. 2B). Another example corresponds to the synthetic secondary fault situated between the Modorra Fault and Fault F7. A GPR profile acquired across an antislope scarp on a fan surface SE of La Aldehuela showed geometries attributable to tilted beds of probable Holocene age truncated by a SW dipping antithetic fault (Fig. 2C).

\section{The Munébrega Half-graben}

The $19 \mathrm{~km}$ long Munébrega Half-graben is superimposed on and inset into the Calatayud Graben along its southwestern margin, south of the Jalón River valley (Fig. 1). The formation of this half-graben depression started after the Lower Pliocene (Gutiérrez, 1998), which is the age of the youngest sediments of the Calatayud Graben fill (Adrover et al., 1982). The NE active margin of the half-graben corresponds to a horst bounded by the Munébrega E Fault and the Munébrega W Fault (Gutiérrez, 1998; Gutiérrez et al., 2009b; Fig. 3A, Table 1). The latter is the master fault that controls the development of the basin. The sedimentary fill, composed of alluvial fan deposits more than $30 \mathrm{~m}$ thick, is poorly exposed due to limited dissection. It overlies an irregular paleorelief and is locally interrupted by intrabasinal inliers of Paleozoic bedrock.

The trace of the NE-dipping Munébrega E Fault is defined by a conspicuous break in slope and its length might reach more than $10 \mathrm{~km}$. South of the Jalón Valley it shows a N155E strike that changes progressively into an ESEWNW trend in its southern sector. About $1 \mathrm{~km}$ east of the Munébrega E Fault there is the $4 \mathrm{~km}$ long Valgalindo alluvial fan inset into the Calatayud Graben fill, whose apex points to a topographic gap in the horst, suggesting deposition in response to tectonic subsidence (Fig. 1). Moreover, several streams show sharp bends controlled by the fault. In an exposure of the Munébrega E Fault on the C-102 road the most recent event on this structure has been post-dated at 7.9 ka by Optically Stimulated Luminescence (OSL) dating of an undeformed deposit that truncates the fault (Gutiérrez et al., 2009b).

The SW-dipping Munébrega W Fault has a sinuous trace and controls a well-defined mountain front $180 \mathrm{~m}$ high with conspicuous triangular and trapezoidal facets developed on Miocene conglomerates. In the northwestern sector of the basin and at the south margin of the Jalón River, the Munébrega W Fault has offset a mantled pediment generating a broad uphill-facing scarp 6-7 m high (Fig. 3B). This mantled pediment used to connect with a terrace of the Jalón River situated at about $45 \mathrm{~m}$ above the current channel. On May 2006, a $40 \mathrm{~m}$ long and $2 \mathrm{~m}$ deep trench was dug across this antislope fault scarp (Figs. 3B and 3C). This was the first paleoseismological trench in the Iberian Chain, revealing the infancy of this type of studies in the region. The excavation exposed a 25-m wide deformation zone with a complex structure (Fig. 3D) consisting of graben and horst blocks in the upper part of the scarp and a double monocline with the crestal sectors affected by subvertical and oversteepened normal faults (Gutiérrez et al., 2009b). The cumulative vertical displacement measured in the trench $(7.4 \mathrm{~m})$ and the available maximum age for the deformation $(72 \mathrm{ka})$ yielded a minimum vertical slip rate of $0.1 \mathrm{~mm} / \mathrm{yr}$. The stratigraphic and structural relationships observed in the trench were explained by a minimum of three faulting events. The first rupture event formed an antislope scarp that acted as a barrier for surface runoff inducing deposition confined to the downthrown block. The two subsequent events are recorded by cross-cutting faults that affect the deposits accumulated in the sediment trap created in the first event. Most probably, the estimated maximum average recurrence of $24 \mathrm{ka}$ is considerably larger than the actual value due to the following reasons: (1) The age of the oldest and most recent events are poorly constrained. (2) The inferred paleoseismic record may under-represent the actual sequence of faulting events. In fact, a cumulative vertical displacement of $7.4 \mathrm{~m}$ close to the termination of the fault seems to be difficult to justify with only three events (ca. $2.5 \mathrm{~m}$ of average vertical displacement per event). It would be desirable to conduct additional trenching investigations on this fault in order to improve the chronology of the paleoseismic record and probably infer a more complete sequence of events. This would allow us to provide more reliable parameters for this seismogenic structure (slip rate, recurrence and elapsed time).

\section{The Daroca Half-graben}

The NW-SE trending Daroca Half-graben is a $27 \mathrm{~km}$ long and up to $8 \mathrm{~km}$ wide depression controlled along its NE active margin by the Daroca Fault (Julivert, 1954; Gracia, 1992a) (Fig. 1). This fault results from the negative inversion of the parallel and adjacent NE-verging Daroca Thrust, on which Cambrian rocks override Lower? Miocene detrital sediments of the Calatayud Basin (i.e. 

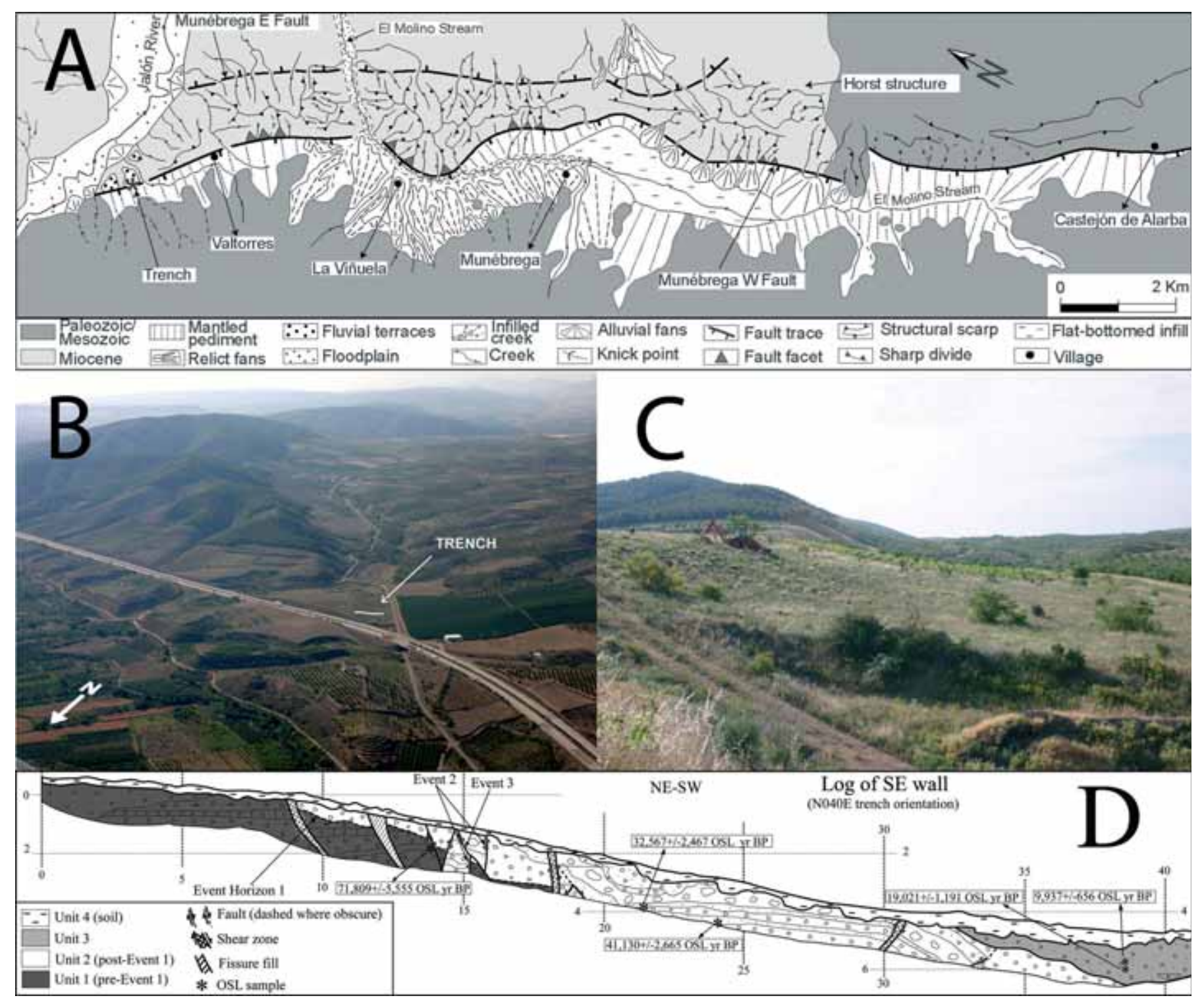

Fig. 3.- A: Geomorphological sketch of the Munébrega Half-graben. The location of the trench excavated in the northern sector of the Munébrega W Fault is indicated. B: Oblique aerial view the Munébrega half-graben. The trace of the Munébrega W Fault is defined by a mountain front (background) and a broad antislope scarp on a mantled pediment (foreground), where a trench was investigated in 2006. C: Uphillfacing fault scarp in the Munébrega W Fault investigated via trenching. D: Simplified sketch of the trench excavated in the Munébrega W Fault (see explanation in text).

Fig. 3.- A: Esquema geomorfológico de la Semifosa de Munébrega. Se indica la localización de la trinchera excavada en el sector septentrional de la Falla de Munébrega Oeste. B: Vista aérea oblicua de la Semifosa de Munébrega. La traza de la Falla de Munébrega Oeste viene definida por un frente montañoso (al fondo) y un amplio escarpe a contra-pendiente (en primer plano) en un glacis, donde se investigó una trinchera en el 2006. C: Escarpe a contra-pendiente asociado a la Falla de Munébrega Oeste en el que se excavó la trinchera. D: Esquema simplificado de la trinchera excavada en la Falla de Munébrega Oeste (explicación en el texto).

Colomer and Santanach, 1988) (Fig. 4). The Daroca Depression is inset with respect to the Calatayud Neogene Graben, thus its generation occurred in Plio-Quaternary times after the infill of the Calatayud Basin. The master Daroca Fault system defines a rectilinear range front of Palaeozoic rocks with truncated bedrock spurs. The sedimentary fill of the basin is more than $100 \mathrm{~m}$ thick and is composed of red detrital sediments consisting of angular Palaeozoic clasts embedded in a clayish matrix, sands and shales. Based on the topographic relationship between the Calatayud and the Daroca basins and on the age of the Calatayud graben sedimentary fill, an Upper Pliocene-Quaternary age has been attributed to this formation, known as the Daroca Detrital Unit (Gracia, 1990, 1992a). The top of this sedimentary unit is conformably overlain by mantled pediments inclined toward the active margin of the graben (Pliocene pediments in Fig. 4). Inset into the Daroca Detrital Unit there is a stepped 


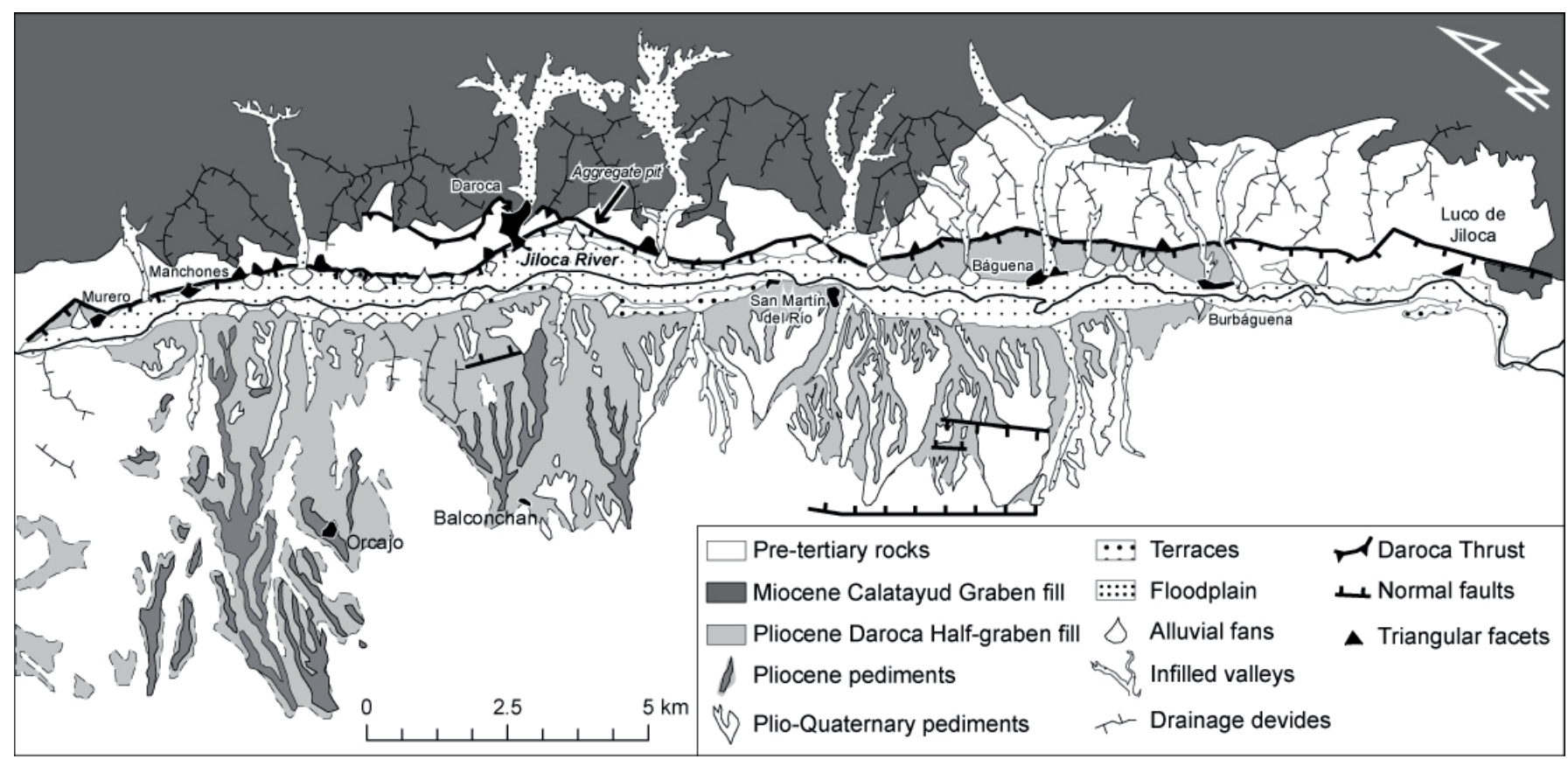

Fig. 4.- Geological map of the Daroca Half-graben (modified from Gracia, 1992).

Fig. 4.- Mapa geológico de la Semifosa de Daroca (modificado de Gracia, 1992).

sequence of alluvial levels (terraces and Plio-Quaternary pediments in Fig. 4) related to the episodic entrenchment of the Jiloca River (Gracia, 1990).

Clear evidence of Quaternary activity on the Daroca Fault is found in an aggregate pit located close to the village of Daroca and next to the N-234 road (see figure 4 for location of the outcrop). Here, the fault juxtaposes Paleozoic argillites in the footwall against two detrital units (U1 and U2), bounded by an angular unconformity in the hanging wall (Gutiérrez et al., 2005, 2008). These units and the fault are truncated and unconformably overlain by an undeformed Holocene cone deposit (U3). A N140E strike and a 50SW dip were measured on the fault plane. The older unit affected by the fault is the Upper Pliocene-Quaternary Daroca Detrital Unit (U1), which dips $25^{\circ}$ to the West. This unit is unconformably overlain by a pale orange unit (U2) that dips $13^{\circ}$ to the SW and is also affected by the fault (Gutiérrez et al., 2008). This deposit corresponds to the oldest alluvial unit inset in the basin fill located at around 35-40 $\mathrm{m}$ above the Jiloca River in its distal sector. It consists of alternating beds of clast-supported angular gravels and fine-grained sediments with a dominant tabular geometry (sheetflood deposits). Two samples of fine-grained facies collected from this unit has yielded ages of 118,673 $\pm 16,237$ and $112,855 \pm 9,145$ OSL yr BP (Gutiérrez et al., 2008). In previous works, when the exposure was very limited, this Upper Pleistocene unit was considered not to be affected by the Daroca Fault (Gracia, 1990, 1992a). Unfortunately, the chronology of the latest fault movement can not be constrained due to the lack of numerical dates from the unit that truncates the fault. In the SE sector of the depression, a Plio-Quaternary mantled pediment inset in the basin fill is affected by a $10 \mathrm{~m}$ high uphill-facing scarp produced by a synthetic secondary fault (Gracia, 1990, 1992a) (Fig. 4). According to a morphometric analysis performed by Gracia (1992b), the anomalously large size of the alluvial fans developed at the foot the main fault provides additional evidence for the recent (Holocene?) activity on Daroca Fault.

\section{The Jiloca Depresion and the Rubielos de la Cérida graben-valleys}

The NNW-SSE trending Jiloca Depression, $70 \mathrm{~km}$ long and around $10 \mathrm{~km}$ wide, is controlled on its eastern margin by three major NW-SE to N-S normal faults with a right stepping en echelon arrangement: Calamocha Fault, Palomera Fault and Concud-Teruel Fault (Fig. 1, Table 1). The association of these faults with parallel NE-verging thrusts and anticlines (Daroca Thrust and Palomera and Cella anticlines, respectively) suggests that they result from the negative inversion of Paleogene thrusts at depth (Cortés, 1999). These master faults define three graben sectors, each of them showing particular morphosedimentary features and different tectonosedimentary evolutions.

The northern sector of the Jiloca Half-graben is partially superimposed on the Calatayud Neogene Graben along the Calamocha and Bañón Faults, 17 and 4 km 


\begin{tabular}{|c|c|c|c|c|c|c|}
\hline & $\begin{array}{l}\text { Strike/dip } \\
\text { orientation }\end{array}$ & $\begin{array}{l}\text { Length } \\
\text { (km) }\end{array}$ & $\begin{array}{l}\text { Geomorphic and stratigraphic evidence of Plio- } \\
\text { Quaternary deformation }\end{array}$ & $\begin{array}{l}\text { Vertical } \\
\text { displace- } \\
\text { ment }(m)\end{array}$ & $M_{w}(W \& C / S)$ & References \\
\hline \multicolumn{7}{|c|}{ Río Grío Graben } \\
\hline Vicort Fault & $\mathrm{N} 135 \mathrm{E} / \mathrm{NE}$ & 15.5 & $\begin{array}{l}\text { Linear mountain front with triangular facets on hard } \\
\text { Paleozoic sandstones up to } 230 \mathrm{~m} \text { high. Faulted } \\
\text { Plio-Quaternary alluvial fan sediments more than } 90 \\
\mathrm{~m} \text { thick in downthrown block. }\end{array}$ & $>90 / ?$ & $6.2 / 6.8$ & $\begin{array}{l}\text { Gutiérrez et al. } \\
(2009 \mathrm{a})\end{array}$ \\
\hline $\begin{array}{l}\text { Modorra } \\
\text { Fault }\end{array}$ & $\mathrm{N} 136 \mathrm{E} / \mathrm{NE}$ & 5.9 & $\begin{array}{l}\text { Linear mountain front with triangular facets on hard } \\
\text { Paleozoic sandstones up to } 140 \mathrm{~m} \text { high. Faulted and } \\
\text { tilted Plio-Quaternary alluvial fan sediments more } \\
\text { than } 30 \mathrm{~m} \text { thick in downthrown block. }\end{array}$ & $>30 / ?$ & $5.9 / 6.5$ & $\begin{array}{l}\text { Gutiérrez et al. } \\
(2009 a)\end{array}$ \\
\hline Fault F3 & N147E/SW & 6.5 & $\begin{array}{l}\text { Linear front with tringaular fault facets up to } 60 \mathrm{~m} \\
\text { high. Offsets alluvial fan deposits developed in the } \\
\text { graben depression controlled by faults F3 and F4 at } \\
\text { their distal edge. }\end{array}$ & $? / ?$ & $5.9 / 6.5$ & $\begin{array}{l}\text { Gutiérrez et al. } \\
(2009 a)\end{array}$ \\
\hline Fault F4 & $\mathrm{N} 146 \mathrm{E} / \mathrm{NE}$ & 5.8 & $\begin{array}{l}\text { Linear range front with step over and triangular } \\
\text { fault facets up to } 60 \mathrm{~m} \text { high. Juxtaposes Plio-Qua- } \\
\text { ternary alluvial fan deposits against Paleozoic rocks. }\end{array}$ & $? / ?$ & $5.9 / 6.5$ & $\begin{array}{l}\text { Gutiérrez et al. } \\
(2009 a)\end{array}$ \\
\hline Fault F5 & N148E/SW & 5 & $\begin{array}{l}\text { Linear mountain front with truncated divides and } \\
\text { triangular facets. }\end{array}$ & $? / ?$ & $5.8 / 6.4$ & $\begin{array}{l}\text { Gutiérrez et al. } \\
(2009 \mathrm{a})\end{array}$ \\
\hline \multicolumn{7}{|c|}{ Munébrega Half-graben } \\
\hline $\begin{array}{l}\text { Munébrega } \\
\text { E Fault }\end{array}$ & $155-110 / \mathrm{NE}$ & $>10$ & $\begin{array}{l}\text { Tectonically-induced Valgalindo alluvial fan on } \\
\text { downthrown block. Conspicuous break in slope and } \\
\text { sharp bends in streams along its trace. }\end{array}$ & $? / ?$ & $6.2 / 6.7$ & $\begin{array}{l}\text { Gutiérrez (1998), } \\
\text { Gutiérrez et al. } \\
(2009 b)\end{array}$ \\
\hline $\begin{array}{l}\text { Munébrega } \\
\text { W Fault }\end{array}$ & $136 / \mathrm{SW}$ & 20 & $\begin{array}{l}\text { Upper Pleistocene pediment (ca. } 72 \mathrm{ka} \text { ) offset } 7.4 \\
\text { m. Linear mountain front with triangular and trap- } \\
\text { ezoidal facets. }\end{array}$ & $\begin{array}{c}7.4 />0.1 \\
(\text { post- } 72 \mathrm{ka})\end{array}$ & $6.6 / 6.9$ & $\begin{array}{l}\text { Gutiérrez (1998), } \\
\text { Gutiérrez et al. } \\
(2009 b)\end{array}$ \\
\hline \multicolumn{7}{|c|}{ Daroca Half-graben } \\
\hline $\begin{array}{l}\text { Daroca } \\
\text { Fault }\end{array}$ & 136/SW & 27 & $\begin{array}{l}\text { Linear mountain front with triangular facets. }>100 \\
\mathrm{~m} \text { thick Upper Pliocene-Pleistocene alluvium } \\
\text { deposited in hanging wall basin. Faulted Pleistocene } \\
\text { pediment deposits (ca. } 113 \mathrm{ka} \text { ). }\end{array}$ & $? / ?$ & $6.7 / 7$ & $\begin{array}{l}\text { Gracia }(1990, \\
\text { 1992), Gutiérrez et } \\
\text { al. (2008) }\end{array}$ \\
\hline \multicolumn{7}{|c|}{ Jiloca Depression } \\
\hline $\begin{array}{l}\text { Calamocha } \\
\text { Fault }\end{array}$ & $141 / \mathrm{SW}$ & 17 & $\begin{array}{l}\text { Fault line scarp with triangular facets. Lower } \\
\text { Pliocene limestones displaced vertically } 140-250 \mathrm{~m} \text {. } \\
\text { Faulted Quaternary alluvial deposits. Thin Plio- } \\
\text { Quaternary sequence beneath valley bottom. }\end{array}$ & $\begin{array}{l}140- \\
250 />0.03- \\
\quad 0.05\end{array}$ & $6.5 / 6.9$ & $\begin{array}{l}\text { Hernández et al. } \\
\text { (1983), Simón } \\
\text { (1983), Gracia } \\
\text { (1990), Gutiérrez } \\
\text { et al. (2008) }\end{array}$ \\
\hline $\begin{array}{l}\text { Palomera } \\
\text { Fault }\end{array}$ & 146/SW & 16 & $\begin{array}{l}\text { Faulted Quaternary alluvial deposits. Anomalously } \\
\text { steep alluvial fans. }\end{array}$ & $? / ?$ & $6.4 / 6.8$ & $\begin{array}{l}\text { Moissenet (1980), } \\
\text { Gracia et al. } \\
(2003)\end{array}$ \\
\hline $\begin{array}{l}\text { Concud- } \\
\text { Teruel Fault }\end{array}$ & $\begin{array}{l}120-010 / \\
\text { SW-W }\end{array}$ & 24 & $\begin{array}{l}\text { Linear range front with triangular facets. Tectonical- } \\
\text { ly-controlled deposition of Late Pliocene limestones } \\
\text { confined to the downthrown block. Tilted and fault- } \\
\text { ed Pliocene limestones and Pleistocene alluvium }\end{array}$ & $>250 />0.06$ & $6.7 / 7$ & $\begin{array}{l}\text { Moissenet (1983), } \\
\text { Simón and Soriano } \\
\text { (1983), Gutiérrez } \\
\text { et al. }(2008,2010) \text {, } \\
\text { Lafuente } \text { et al. } \\
(2010 b, 2011)\end{array}$ \\
\hline
\end{tabular}

Table 1.- Main features of the Quaternary faults more than $5 \mathrm{~km}$ long identified in the Plio-Quaternary tectonic depressions of the central sector of the Iberian Chain. Expected earthquake moment magnitudes $\left(\mathrm{M}_{\mathrm{w}}\right)$ are based on fault length and the regressions proposed by Wells and Coppersmith (1994) and Stirling et al. (2002). The regressions by Wells and Coppersmith (1994) are based on a smaller data set and tend to underestimate earthquake magnitude when applied to mapped fault traces.

Tabla 1.- Principales características de las fallas cuaternarias de más de $5 \mathrm{~km}$ de longitud identificadas en la depresión tectónica Plio-Cuaternaria del sector central de la Cadéna Ibérica. Las magnitudes momento esperadas (Mw) están basadas en la longitud de las fallas y en las regresiones propuestas por Wells and Coppersmith (1994) y Stirling et al. (2002). Las regresiones de Wells and Coppersmith (1994) están basadas en un menor conjunto de datos y tienden a subestimar la magnitud cuando se aplican a trazas de fallas cartografiadas. 
long, respectively. According to Hernández et al. (1983), the Calamocha Fault in its northern sector (Venta de los Céntimos area) has downthrown vertically $250 \mathrm{~m}$ Lower Pliocene limestones of the Calatayud Basin fill into the Jiloca Depression. Nonetheless, the 1:50,000 scale geological sheets of of Hernández et al. (1983a; 1983b), Daroca (465) and Calamocha (491), indicate a vertical distance of $140 \mathrm{~m}$ between the base of the Lower Pliocene limestones at both sides of the fault, SE of Nombrevilla and SW of Lechago. Considering a maximum time span of 5.3 Ma for the deformation (base of the Pliocene), a minimum slip rate of $0.03-0.05 \mathrm{~mm} / \mathrm{yr}$ can be attributed to this fault. The Calamocha and Bañón faults also displace Pleistocene alluvial fan deposits in outcrops located at the Zaragoza-Teruel railway east of Calamocha $(\mathrm{Gu}-$ tiérrez et al., 1983a, Simón, 1983; Gracia, 1990) and in a cutting of the Caminreal-Bañón road (Gracia, 1990), respectively. Unfortunately, it is not possible to tightly constrain the timing of these deformations due to the lack of numerical dates. To the west of Calamocha village (Fig. 1), Gracia (1990) mapped several NW-SE secondary synthetic and antithetic faults, one of them expressed as an upslope-facing scarp around $5 \mathrm{~m}$ high offsetting the surface of an Upper Pliocene-Pleistocene mantled pediment. In the central sector of the depression borehole data reveal the following stratigraphic sequence: (1) Red alluvial fan facies of supposed Upper Pliocene age. (2) Organic-rich lacustrine sediments ca. 50 m thick. (3) Tufaceous terrace deposits more than $35 \mathrm{~m}$ thick, dated at $312 \mathrm{ka}$ by U/Th from a sample collected $4 \mathrm{~m}$ beneath the surface (Gracia, 1990, 1993; Gracia and Cuchí, 1993). These data indicate that this sector of the half-graben has undergone long-sustained synsedimentary tectonic subsidence in Upper Pliocene and Quaternary times.

In the transition zone between the northern and central sector of the Jiloca Depression, between Monreal del Campo and Caminreal, there is an extensive outcrop of Miocene detrital sediments; that is, negligible Plio-Quaternary fill. The central sector of the Jiloca Depression, from Monreal del Campo to Cella, is mostly developed on soluble Jurassic carbonate rocks and has behaved as an endorheic area until its artificial drainage in historical times (Gracia et al., 2003; Rubio et al., 2007 and references therein). In this sector the basin is bounded on its eastern margin by the more than $400 \mathrm{~m}$ high Palomera Fault mountain front. On the western margin of the depression, Gracia et al. (2003) mapped eight staircased levels of corrosion surfaces with a slight inclination towards the active margin of basin, partly attributable to tectonic tilting. The bottom of the depression, with a relatively flat topography, includes: (1) Pediments cut-across Jurassic limestone along most of the foot of the Palomera
Range. That is, there is no or very thin sedimentary cover on the hanging wall next to the Palomera Fault (Fig. 5A). (2) Alluvial fans typically underlain by alluvium tens of meters thick and locally interrupted by inliers of Jurassic bedrock up to $90 \mathrm{~m}$ high. These alluvial deposits are locally affected by synthetic and antithetic faults of unknown throw (Moissenet, 1980; Gracia et al., 2003). (3) Large artificially drained flood-prone (Mierla Plain) and lacustrine areas (Cañizar Lake). A borehole drilled in El Cañizar Lake located in axial sector of the basin, close to Villarquemado (Fig. 1), indicates a sedimentary fill composed of peatbog, alluvial fan and carbonate lake deposits more than $74 \mathrm{~m}$ thick. The OSL dates obtained at the base of the drilled succession (121-116 ka; Moreno et al. 2010) indicate an average aggradation rate of around $0.6 \mathrm{~mm} / \mathrm{yr}$. This figure suggests an anomaluously high subsidence rate that might be related to the contribution of both tectonic subsidence and subsidence due to dissolution of the underlying Triassic evaporites in this major karstic discharge area. The Río Seco monocline described below and situated 20-25 km to the SE could be an observable analogue for this hypothesis (Calvo et al., 1999; Gutiérrez et al., 2011).

This sector of the Jiloca Depression has received different genetic interpretations, with relevant implications for the assessment of the activity and seismogenic potential of the Palomera Fault. Cortés (1999) and Cortés and Casas (2000) proposed that the formation of the Jiloca Depression is primarily related to erosional processes accompanied by the development of nested planation surfaces (pediplains) on the western margin. These authors, based on the null or very limited thickness of the basin fill, considered that the prominent relief of this range front is chiefly due to structurally-controlled differential erosion and estimated on this fault a vertical throw of a few tens of meters. Gracia et al. (2003) interpreted the central sector of the Jiloca Depression as a karst polje developed within an active half-graben, a common situation in a number of Alpine orogens (e.g. Gams, 2005; Aiello et al., 2007). These authors suggest that a great part of the topographic relief of the depression is the result of episodic corrosional lowering interrupted by periods of planation controlled by the water table, as record the steeped sequence of rock-cut surfaces developed on the western margin. Other authors indicate that the topographic depression is primarily due to tectonic subsidence and, in the absence of correlatable geomorphic or stratigraphic markers on both sides of the structure, propose a PlioQuaternary vertical displacement of $350-400 \mathrm{~m}$ on the Palomera Fault (Rubio and Simón, 2007; Rubio et al., 2007; Simón et al., 2010). Gracia et al. (2008), in agreement with Cortés and Casas (2000), argue that such a tec- 


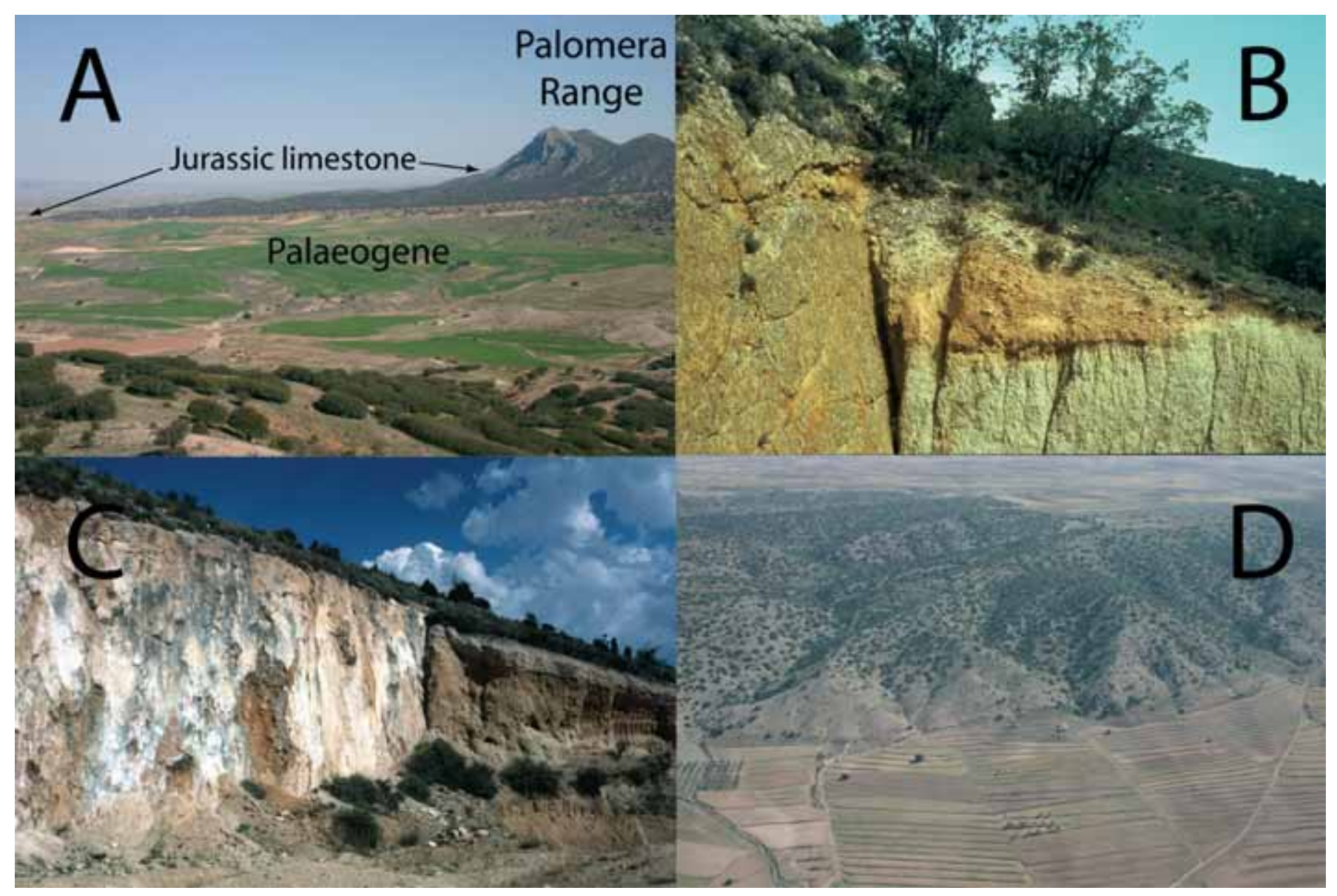

Fig. 5.- A: Lateral view of the Palomera mountain front with an extensive pediment cut-across Jurassic limestones at the foot of the range, in the sector where it reaches the highest elevation. Photograph taken from the south of the range. B: Fault offsetting two colluvial units separated by an angular unconformity (Torrelacárcel-Aguatón road). The youngest unit has been dated on the basis of archeological remains at 1,200-500 yr B.C. (Burillo et al., 1985). C: Normal fault juxtaposing Jurassic carbonate rocks and late Pleistocene colluvial deposits at the margin of one of the graben-valleys of Rubielos de la Cérida. D: Aerial view of Concud Fault mountain front, showing triangular facets and truncated mantled pediment deposits in the proximal sector.

Fig. 5.- A: Vista lateral del frente montañoso de Palomera con un extenso pedimento desarrollado en calizas jurásicas al pie, en el sector donde la sierra alcanza su mayor altura. Imagen tomada desde el sur. B: Falla normal afectando a dos unidades coluviales separadas por una discordancia angular (carretera Torrelacárcel-Aguatón). La unidad más reciente ha sido datada mediante restos arqueológicos en 1.200-500 A.C. (Burillo et al., 1985). C: Falla normal poniendo en contacto calizas jurásicas y depósitos coluviales del Peistoceno superior en el margen de una dos los valles tectónicos de Rubielos de la Cérida. D: Vista aérea del frente montañoso de la Falla de Concud, mostrando facetas triangulares y depósitos de glacis truncados en su sector proximal.

tonic subsidence in an endorheic half-graben would be recorded by a thick sedimentary sequence on the downthrown block next to the master fault, and not by rock-cut pediments on Jurassic rocks devoid of any cover (Fig. 5A). Gracia et al. (2008) also question the reliability of the ages assigned to the lithostratigraphic units differentiated by Rubio and Simón (2007). Regardless of the origin of the depression, we consider that with the available data it is not possible to assess unambiguously the cumulative vertical offset and slip rate on the Palomera Fault. Nonetheless, the Palomera Fault should be considered as a seismogenic structure capable of producing large magnitude earthquakes owing to the fact that it locally offsets recent deposits.
The only Quaternary faults in the central sector of the Jiloca Depression whose chronology has been constrained by numerical dating are located in the eastern upthrown block of the basin. Burillo et al. (1985) interpreted two faulting events from two unconformable colluvial units affected by a NW-SE trending and NE dipping fault located $1.5 \mathrm{~km}$ east of the Palomera Fault (TorrelacárcelAguatón road; Fig. 5B). According to the archeological dating of the youngest colluvial unit, the displacement events occurred before and after 1,200-500 yr BC. This is probably the first and youngest paleoseismic record documented in the Iberian Chain.

On the eastern margin of the Jiloca Depression and associated to the step over between the Calamocha- 
Bañón and Palomera Faults, there is a series of narrow graben-valleys with a prevailing N-S trend less than 4 $\mathrm{km}$ long and 0.1-0.8 km wide. The linear fault-controlled margins of these colluvium- and alluvium-filled depressions show bedrock scarps and triangular facets. A gravel pit in the Caminreal-Rubielos de la Cérida road exposes a normal fault juxtaposing Jurassic carbonates against a colluvial sequence $8.4 \mathrm{~m}$ thick (Capote et al., 1981; Gutiérrez et al., 1983a, b; Fig. 5C). Charcoal pieces collected at $2.1 \mathrm{~m}$ and $7.9 \mathrm{~m}$ below the surface have yielded ages of $43,070 \pm 120014 \mathrm{C} \mathrm{yr} \mathrm{BP}$ and $>48,500 \mathrm{yr}$ BP, respectively (Gutiérrez et al., 2008). The youngest age indicates an average aggradation rate of $0.05 \mathrm{~mm} /$ $\mathrm{yr}$, which could be considered as a rough estimate for the vertical slip rate. The short length of the mapped faults in the area suggests that they correspond to secondary structures. There is also the possibility that subsidence in these grabens with anomalously low aspect ratios (width/ length) and frequent sinkholes could be partially related to the karstification of the underlying Jurassic carbonates and Triassic evaporites (Gutiérrez et al., 2008). Similar morpho-structures related to interstratal karstification of evaporites have been documented in northern Michigan, Canada (Black, 1997).

The southern sector of the Jiloca Depression, controlled by the $24 \mathrm{~km}$ long Concud-Teruel Fault, is superimposed on the west-central sector of Teruel Neogene Graben (Fig. 1). The Concud Fault, with a general NW-SE strike, turns into a N-S direction in the western margin of the Alfambra River valley, cropping out further south at the opposite side of the valley with a N-S trend, where it is named Teruel Fault (Gutiérrez et al., 2008). This fault has displaced vertically more than $250 \mathrm{~m}$ Lower Pliocene limestones of the Teruel Basin fill. Considering this minimum vertical offset and a maximum time span of 4.2 Ma, which is the base of the MN15 Mein biozone (age of youngest sediments dated biostratigraphically in both walls of the fault; Mein et al., 1989-90), a minimum vertical slip rate of $0.06 \mathrm{~mm} / \mathrm{yr}$ can be estimated for this structure (Gutiérrez et al., 2008). The Concud Fault portion controls a mountain front with triangular facets on Jurassic limestone (Fig. 5D). In the downthrown block, "exorheic" Late Pliocene alluvial fan sediments overlie, unconformably and over an excavation surface, "endorheic" Pliocene limestones (Mein et al., 1989-1990; Gutiérrez et al., 2008). These alluvial fan sediments are capped unconformably by mantled pediment deposits. In our opinion, geomorphic indexes calculated for this mountain front (Lafuente et al., 2008a), in which base level changes and geomorphic processes have been controlled by both active tectonics and significant erosion in the downthrown block, are not comparable with those ob- tained in tectonic basins dominated by aggradation (e.g. Bull, 2007); may lead to substantial overestimates of the tectonic activity.

The first paleoseismological interpretation for the outcrop of Concud Fault at Los Baños railway trench, situated at the western margin of the Alfambra River valley, was given by Gutiérrez et al. $(2005,2008)$. These authors interpreted a minimum of four faulting events younger than $72 \mathrm{ka}$. The oldest event is recorded by an angular unconformity and the subsequent events by three generations of fissure fills associated with the master fault. Lafuente et al. $(2010,2011)$ inferred a minimum of six paleoseismic events, adding two events to the previous interpretation. Gutiérrez et al. (2011) discussed that the two extra events are unnecessary to explain the geometrical relationships exposed in the outcrop (Fig. 6). Concerning the oldest extra event, they consider that it is not possible to demonstrate that the units situated below the proposed event horizon are affected by a faulting event that does not affect the overlying unit. Regarding the youngest extra event (faulting of a colluvial wedge), they indicate the following considerations: (1) The deposits attributed to a faulted colluvial wedge correspond to two different units. (2) There is no way to know the original geometry of the unit interpreted as a colluvial wedge, since its upper limit corresponds to a channel erosional surface. (3) The unit interpreted as a colluvial wedge has an erosional base that dips toward the fault when retrodeformed considering the dip of the overlying strata. Additional discussion on this issue, average recurrence, segmentation and Quaternary slip rates of Concud-Teruel Fault may be found in Gutiérrez et al. (2011) and Lafuente et al. (2011).

At the eastern margin of the Alfambra valley and close to the trace of the N-S trending Teruel Fault segment, a young terrace (14.9 \pm 1.0 OSL ka; Gutiérrez et al., 2008) is affected by faults on two orthogonal road cuttings. Here, the Triassic evaporitic bedrock is situated at shallow depth beneath the Miocene sequence. Lafuente et al. (2010b, 2011) attribute these structures to the most recent exposed and dated event on Concud Fault, bracketed at

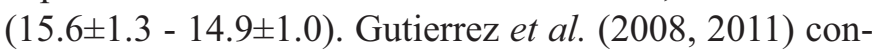
sider that those failure planes may have a gravitational origin (i.e. subsidence due to evaporite dissolution).

\section{The Río Seco Monocline and Graben}

The Rio Seco creek and Los Mansuetos mesa are located in the central sector of Teruel Neogene graben and on the SE margin of the Jiloca morpho-structural depression (Fig. 1). In the NW flank of this mesa, the Mio-Pliocene sequence, including the fossil-rich sections proposed for the definition of the Turolian stage, has subsided due to 
Fig. 6.- Sketch and photograph of the critical sector of the outcrop of Concud Fault at Los Baños site. Gutiérrez et al. $(2005,2008)$ interpreted the base of unit 4 as an event horizon. Lafuente et al. (2010) added two extra faulting event; an additional event horizon at the base of unit 3 ascribed to a paleosoil and faulting of a supposed colluvial wedge corresponding to units 4 and $\mathrm{X}$. Note the erosional lower and upper boundaries of unit 4 .

Fig. 6.- Esquema y fotografía del sector clave del afloramiento de la Falla de Concud en Los Baños. Gutiérrez et al. $(2005,2008)$ interpretaron la base de la unidad 4 como un "event horizon". Lafuente et al. (2010) añaden dos eventos de rotura; un event horizon en la base de la unidad 2, que interpretan como un paelosuelo y el desplazamiento de una supuesta cuña coluvial correspondiente a las unidades $4 \mathrm{y}$ $\mathrm{X}$. Nótese el carácter erosivo de los límites superior e inferior de la unidad 4.

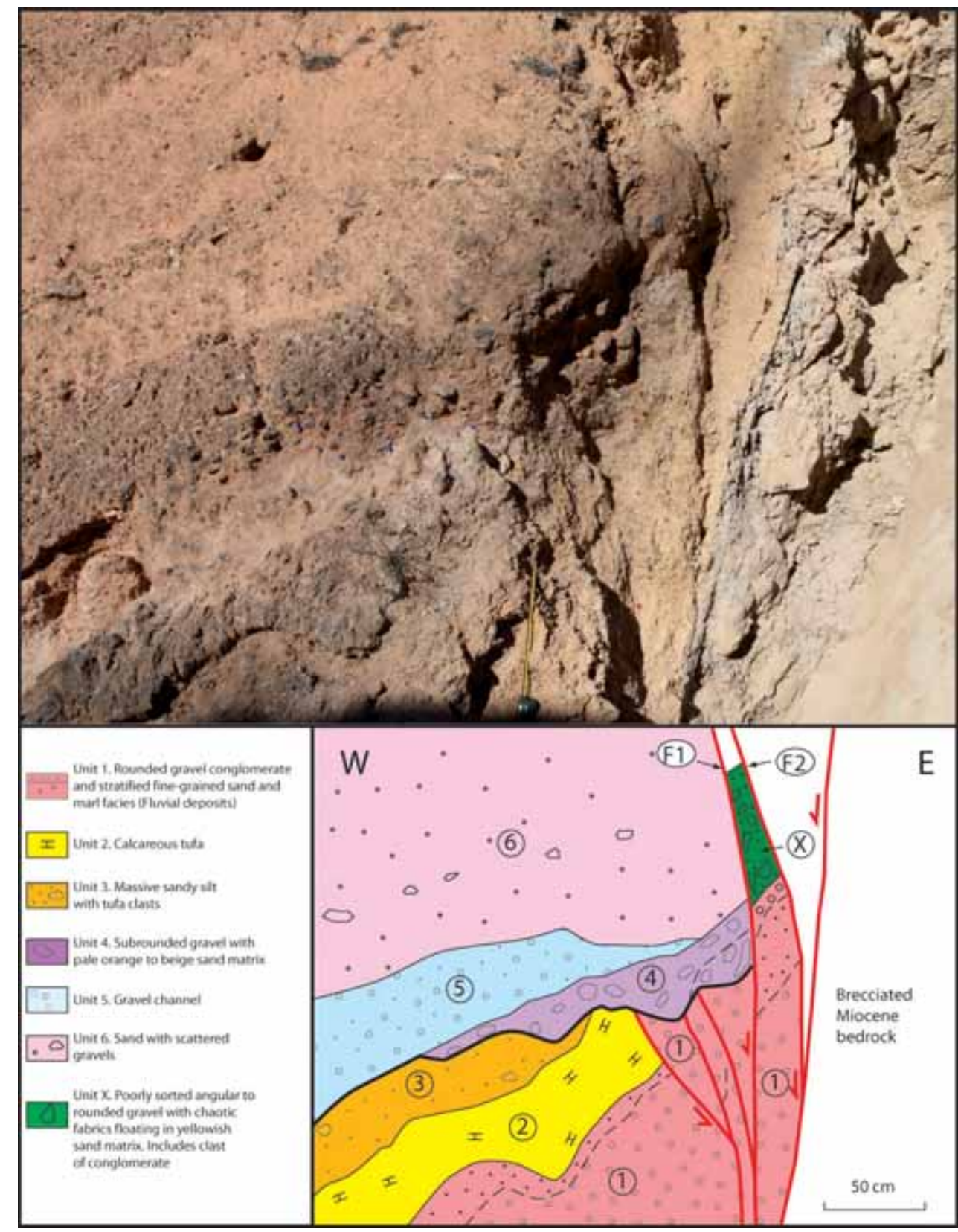

interstratal dissolution of the underlying Triassic evaporites (Gutiérrez, 1998; Calvo et al., 1999). Gravitational passive bending has produced a $1.7 \mathrm{~km}$ long monocline with a synform in the lower flexure (Fig. 7A). The Río Seco valley follows concordantly the NW-SE trending syncline with a structural relief of $130 \mathrm{~m}$. The SE margin of the valley corresponds to the dip slope that forms the $\mathrm{NW}$-facing monoclinal scarp. The crest of the monocline is affected by a keystone graben $1.7 \mathrm{~km}$ long controlled by a master synthetic normal fault and a swarm of antithetic and synthetic secondary faults. This extensional structure counterbalances the shortening caused by gravitational sagging in the adjacent syncline. Three trenches have been excavated across depressions associated with uphill-facing scarps (Fig. 7B) in order to explore criteria that might help to differentiate between tectonic (seismogenic) and gravitational (nonseismogenic) faults (Gutiérrez et al., 2011). To our knowledge, these are the first trenches dug across active faults generated by deep-seated evaporite dissolution. The stratigraphical and structural relationships observed in two of the trenches revealed evidence of Late Holocene episodic displacement (as many as 3 faulting events). Additionally, some of the estimated parameters clearly differ from those expectable for tectonic faults in this intraplate setting: (1) High aspect ratio (Maximum height/Length) of the downhill-facing scarps, with an average value of 0.029. (2) High apparent vertical slip rates; 0.6-1 mm/yr. (3) Low recurrence of faulting events; 1.2-2 ka. (4) Estimated values for the displacement per event on these surface ruptures less than $200 \mathrm{~m}$ 


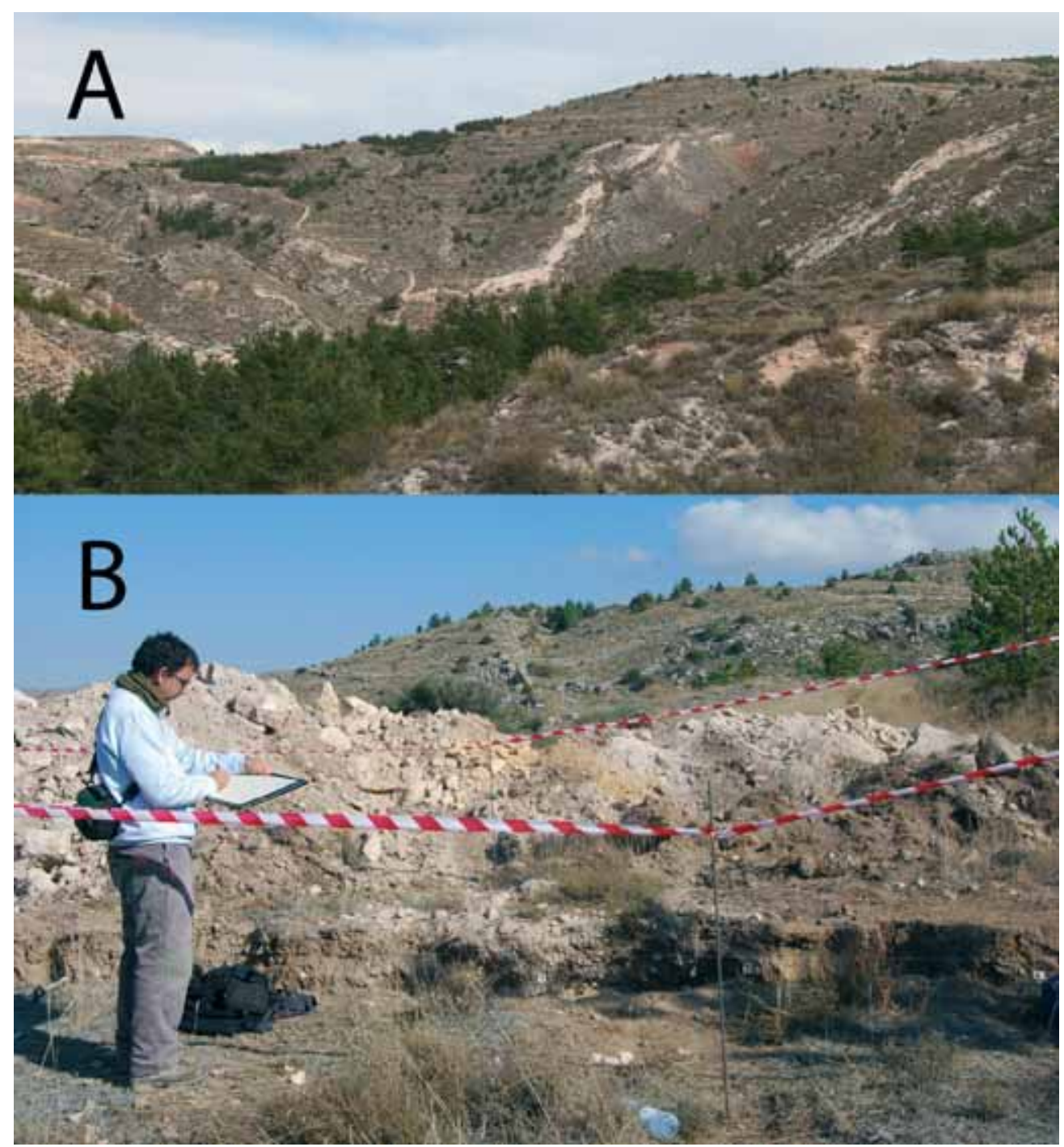

Fig 7.- A: General view of the NE sector of the Rio Seco gravitational syncline and monocline, the latter affected by a crestal graben. B: Upphill-facing scarp in the background and trench excavated across an antislope scarp and accompanying trough in the foreground.

Fig. 7.- A. Vista general del sector NE del sinclinal y monoclinal de Río Seco, generados por karstificación interestratal de evaporitas. La cresta del monoclinal está afectada por una fosa. B: Al fondo, escarpe orientado ladera arriba, y en primer plano, trinchera excavada en otro escarpe a contra-pendiente y en la depresión adyacente.

long are higher than $0.65 \mathrm{~m}$. Average displacements of such amount are expectable for normal fault surface ruptures around $28 \mathrm{~km}$ long (Wells and Coppersmith, 1994). Evidence of stick-slip displacement is commonly used as a criterion to differentiate between tectonic (seismogenic) and dissolution-collapse (nonseismogenic) faults in areas underlain by evaporites (Hanson et al., 1999). The findings of Gutiérrez et al. (2011) strongly suggest that this criterion is not reliable, having relevant implications for seismic hazard assessment in regions where evaporite dissolution plays a role on active deformation, as might be the case in some areas of the Spanish Territory (Gutiérrez et al., 2001, 2012).

\section{Final considerations}

Although the available geological information indicates that there is a considerable number of active faults in the Iberian Chain capable of producing large earthquakes $(\mathrm{Mw}>6.5)$, the existing probabilistic seismic hazard analyses (PSHA) are solely based on instrumental and historical earthquake catalogues, the European-Mediterranean Seismic Hazard Map (Jiménez et al., 2001, 2003; Giardini et al., 2003), and the official seismic hazard map of Spain (Ministerio de Fomento, 2002, 2003). In both PSHAs the seismic activity of the different seismotectonic zones was characterised by their Gutenberg-Richter relationship truncated at a supposed maximum earthquake magnitude based on the historical and instrumental records. The largest historic seismic event in the Iberian Chain is the 18 March 1817 Arnedillo earthquake, with an EMS-98 intensity (European Macroseismic Scale 1998) of VII-VIII and an estimated moment magnitude of 5.7. Giardini et al. (2003) estimated a peak ground acceleration for a 475 -year return period of $0.08 \mathrm{~g}\left(\mathrm{~g}=9.8 \mathrm{~m} / \mathrm{s}^{2}\right)$, whereas the official PSHA (Ministerio de Fomento 2002, 2003) assigns an acceleration below $0.04 \mathrm{~g}$ for a 500 -year return period. Consequently, the current regulations do not establish any requirement for earthquake-resistant building in the Iberain Chain. However, the geological 
knowledge on Quaternary faults, although still quite limited, suggests that the assessments provided by the Spanish Government underestimate the seismic hazard. In the Iberian Chain, where the seismic cycles are considerably longer than the time span covered by the historical and instrumental record, more realistic predictions could be produced incorporating the known active faults and their seismogenic potential in the seismic hazard analyses. For this purpose, if would be desirable to generate a data base of tectonic Quaternary faults as complete as possible and a sound seismic characterization of each capable structure (magnitude, slip rate, recurrence and elapsed time).

Recently, two new Plio-Quaternary grabens have been documented by means of detailed geomorphological mapping. This fact suggests that the current knowledge on the distribution of Quaternary faults in the Iberian Chain is still limited. Probably, one of the reasons why the newly reported Quaternary faults had been overlooked is due to the scarce attention that has been traditionally paid in geological mapping programs to recent landforms and deposits, which constitute the markers that allow the identification and characterization of active tectonic structures. For example, in Colorado, USA, the increased attention given to surficial formations in the new geological maps is contributing considerably to improve the knowledge on Quaternary tectonic faults (McCalpin, 2008). The length of the mapped faults in the Iberian Chain $(<26-27$ $\mathrm{km})$ suggests that earthquakes with moment magnitudes larger than 7 might not be expected in the area (Stirling et al., 2002). The maximum credible earthquake in some areas may change substantially depending on whether some faults are considered as single or segmented seismic sources (e.g. Concud-Teruel Fault).

Available data on long-term slip rate, a parameter usually applied to estimate indirectly earthquake recurrence assuming no interseismic displacement, is still limited due to the following reasons: (1) Some faults do not have correlatable markers on both walls, precluding reliable estimates of cumulative displacement and slip rate (e.g. Palomera Fault). In some cases, indirect rough estimates could be made considering the thickness of sediments accumulated in the hanging wall depressions. (2) The slip rates calculated for some faults are based on old (Lower Pliocene) stratigraphic markers (Calamocha Fault and Concud-Teruel Fault). The activity of those faults in late Quaternary times might be different from the average obtained considering a much larger time span ( 4-5 Ma). (3) The chronology of the Quaternary stratigraphic and geomorphic markers associated with some faults is poorly constrained and in some cases correlations are uncertain.

Our capability to estimate earthquake recurrence and elapsed time is largely limited due to the scarcity of paleoearthquake data. Paleoseismological investigations are in their infancy in the Iberian Range. The first paleosesimological trench was excavated in 2006 and only two faults have been studied from a paleoseismological perspective (Munébrega W Fault and Concud-Teruel Fault). Despite geologists have profusely investigated neotectonics in the Iberian Range since the 1980's, "paleoseismic evidence" has not been applied as a conceptual tool until a few years ago. For example, the well-known artificial outcrop of Concud Fault at Los Baños (Moissenet, 1983) received the first paleoseismological interpretation few years ago (Gutiérrez et al., 2005). On the other hand, the paleoseismic record inferred for the Munébrega W Fault probably under-represents the actual sequence of events and the outcrop of Concud Fault at Los Baños has received two different interpretations. The considerations indicated above suggest that a great deal of multidisciplinary geological investigations is needed to produce a complete data base of Quaternary faults in the Iberian Chain and assess their seismogenic potential.

\section{Acknowledgements}

This research has been partially funded by projects CGL2010-16775 (Ministerio de Ciencia e Innovación and FEDER) and DO-SMS-SOE1/P2/F157 (Interreg IV B SUDOE, EU-FEDER).

\section{References}

Adrover, R., Feist, M., Hugueney, M., Mein, P., Moissenet, E. (1982): L'âge et la mise en relief de la formation détritique culminante de la Sierra Pelarda (prov. de Teruel, Espagne). Comptes Rendus de l'Academie des Sciences. Série II, Paris 295: 231-236.

Aiello, G., Ascione, A., Barra, D., Munno, R., Petrosino, P., Russo Ermolli, E., Villani, F. (2007): Evolution of the late Quaternary San Gregorio Magno tectono-karstic basin (southern Italy) inferred from geomorphological, tephrostratigraphical and paleoecological analises: tectonic implications. Journal of Quaternary Science 22, 233-245. doi: 10.1002/jqs. 1040.

Anadón, P., Roca, E. (1996): Geological setting of the Tertiary basins of Northeast Spain. In: P. Friend, C.J. Dabrio (eds.), Tertiary basins of Spain, the stratigraphic record of crustal kinematics. Cambridge University Press, Cambridge: 43-48.

Black, T.J. (1997): Evaporite karst of Northern Lower Michigan. Carbonates and Evaporites 12, 81-83.

Bull, W.B. (2007): Tectonic geomorphology of mountains. Blackwell, Oxford: $316 \mathrm{p}$.

Burillo, F., Gutiérrez, M., Peña, J.L. (1985): Datación arqueológica de deformaciones tectónicas en vertientes holocenas de Sierra Palomera (Cordillera Ibérica centroriental). Actas da I Reunião do Quaternário Ibérico, Lisboa, Vol. 2: 355-366.

Calvo, J.P., Alcalá, L., Alonso-Zarza, A.M., van Dam, J., Gutiérrez Santolalla, F. (1999): Estratigrafía y estructura del área de Los Mansuetos (Cuenca de Teruel). Precisiones para la definición del estratotipo del Turoliense. Geogaceta 25, 55-58. 
Capote, R., Gutiérrez, M., Hernández, A., Olivé, A. (1981): Movimientos recientes en la Fosa del Jiloca (Cordillera Ibérica). $V$ Reunión del Grupo Español de Trabajo del Cuaternario, Sevilla: 245-257.

Capote, R., Muñoz, J.A., Simón, J.L., Liesa, C.L., Arlegui, L.E. (2002): Alpine tectonics I: the Alpine system north of the Betic Cordillera. In: W. Gibbons, T. Moreno (eds.), The Geology of Spain. The Geological Society, London: 367-400.

Colomer, M., Santanach, P. (1988): Estructura y evolución del borde suroccidental de la Fosa de Calatayud-Daroca. Geogaceta 4, 29-31.

Cortés, A.L. (1999): Evolución tectónica reciente de la Cordillera Ibérica, Cuenca del Ebro y Pirineo centro-occidental. $\mathrm{PhD}$ Thesis, University of Zaragoza: $406 \mathrm{p}$.

Cortés, A.L., Casas, A.M. (2000): ¿Tienen el sistema de fosas de Teruel origen extensional? Revista de la Sociedad Geológica de España $13,445-470$

Gams, I. (2005): Tectonic impacts on poljes and minor basins (case studies of Dinaric Karst). Acta Carsologica 34, 25-41.

Giardini, D., Jiménez, MJ., Grünthal, G. (2003): European-Mediterranean Seismic Hazard Map. European Seismological Commission. http://wija.ija.csic.es/gt/ earthquakes/.

Gracia, J. (1990): Geomorfología de la Región de Gallocanta (Cordillera Ibérica Central). PhD Thesis, University of Zaragoza: 660 p.

Gracia, F.J. (1992a): Tectónica pliocena de la Fosa de Daroca (prov. de Zaragoza). Geogaceta 11, 127-129.

Gracia, F.J. (1992b): Conos de deyección, red fluvial y neotectónica en el valle medio del río Jiloca (provs. de Zaragoza y Teruel). In: F. López-Bermúdez, C. Conesa, M.A. Romero (eds.), Estudios de Geomorfología en España. S.E.G., Murcia, vol. 2: 633-642.

Gracia, F.J. (1993): Evolución cuaternaria del río Jiloca (Cordillera Ibérica Central). In: M.P. Fumanal, J. Bernabeu (eds.), Estudios sobre Cuaternario. Medios Sedimentarios. Cambios Ambientales. Hábitat Humano. Asociación Española para el Estudio del Cuaternario, Valencia: 43-51

Gracia, F.J., Cuchí, J.A. (1993): Control tectónico de los travertinos fluviales del río Jiloca (Cordillera Ibérica central). Actas II Reunión del Cuaternario Ibérico. AEQUA y CTPEQ. Madrid-1989: Vol. 2, p. 697-706.

Gracia, F.J., Gutiérrez, F., Gutiérrez, M. (2003): The Jiloca karst polje-tectonic graben (Iberian Range, NE Spain). Geomorphology 52, 215-231. doi: 10.1016/S0169-555X(02)00257-X.

Gracia, F.J., Gutiérrez, F., Gutiérrez, M. (2008): Discussion of "Tectonic subsidence $\mathrm{v}$. erosional lowering in a controversial intramontane depression: the Jiloca basin (Iberian Chain, Spain)". Geological Magazine 145, 591-594. Doi.: 10.1017/S0016756808004895.

Gutiérrez, F. (1998): Fenómenos de subsidencia por disolución de formaciones evaporíticas en las fosas neógenas de Teruel y Calatayud. $\mathrm{PhD}$ Thesis, University of Zaragoza: $569 \mathrm{p}$.

Gutiérrez, F., Ortí, F., Gutiérrez-Elorza, M., Pérez-González, A., Benito, G., Gracia-Prieto, J., Durán, J.J. (2001): The stratigraphical record and activity of evaporite dissolution subsidence in Spain. Carbonates and Evaporites 16(1), 46-70.

Gutiérrez, F., Gracia, J., Gutiérrez, M. (2005): Karst, neotectonics and periglacial features in the Iberian Range. In: G. Desir, F. Gutiérrez, M. Gutiérrez (eds.), Sixth International Conference on Geomorphology Field Trip Guides, Vol. I, Zaragoza: 343-397.

Gutiérrez, F., Gutiérrez, M., Gracia, F.J., McCalpin, J.P., Lucha, P., Guerrero, J. (2008): Plio-Quaternary extensional seismotectonics and drainage network development in the central sector of the Iberian Range (NE Spain). Geomorphology 102(1), 21-42. doi: 10.1016/j.geomorph.2007.07.020.

Gutiérrez, F., Linares, R., Roqué, C., Zarroca, M., Galve, J.P., Carbonel, D., Rosell, J. (2012): Investigating gravitational grabens related to lateral spreading and evaporite dissolution subsidence by means of detailed mapping, trenching and electrical resistivity tomography (Spanish Pyrenees). Lithosphere, in press.

Gutiérrez, F., Lucha, P., Jordá, L. (2009a): The Río Grío depression (Iberian Range, NE Spain). Neotectonic graben vs. fluvial valley. In: R. Pérez-López, C. Grützner, J. Lario, K. Reicherter, P. Silva (eds.), Archeoseismology and Palaeoseismology in the AlpineHimalayan collisional zone. 1st INQUA-IGCP-567 International Workshop on Earthquake Archaeology and Palaeoseismology, Baelo Claudia, Spain: 43-46.

Gutiérrez, F., Masana, E., González, A., Guerrero, J., Lucha, P., McCalpin, J.P. (2009b): Late Quaternary paleoseismic evidence on the Munébrega Half-graben fault (Iberian Range, Spain). International Journal of Earth Sciences 98, 1691-1703. doi: 10.1007/s00531008-0319-y.

Gutiérrez, F., Lucha, P., Guerrero, J., Gutiérrez, M., Carbonel, D. (2011): Discussion on the article "Paleoseismological analysis of an intraplate extensional structure: the Concud fault (Iberian Chain, Eastern Spain)" by P. Lafuente, L.E. Arlegui, C.L. Liesa, J.L. Simón. International Journal of Earth Sciences. doi: 10.1007/ s00531-011-0660-4.

Gutiérrez, F., Carbonel, D., Guerrero, J., McCalpin, J.P., Linares, R. Roque, C., Zaroca, M. (2012): Late Holocene episodic displacement on fault scarps related to interstratal dissolution of evaporites (Teruel Neogene Graben, NE Spain). Journal of Structural Geology 34, 2-19. doi: 10.1016/j.jsg.2011.11.006.

Gutiérrez, M., Gracia, F.J. (1997): Environmental interpretation and evolution of the Tertiary erosion surfaces in the Iberian Range (Spain). In: M. Widdowson (ed.), Geological Paleosurfaces: Recognition, Reconstruction and Palaeoenvironmental Interpretation. Spec. Publ. Geol. Soc. London 120, 147-158. doi:10.1144/GSL. SP.1997.120.01.10

Gutiérrez, M., Peña, J.L., Rodríguez, J., Simón, J.L. (1983a): Criterios geomorfológicos aplicados al estudio de la neotectónica en áreas continentales (ejemplos en la Cadena Ibérica, Depresión del Ebro y Pirineos). Primeras jornadas sobre neotectónica y su aplicación al análisis de riesgos de emplazamientos energéticos e industriales. J.E.N., Madrid: 158-213.

Gutiérrez, M., Peña, J.L., Simón, J.L. (1983b): Los valles tectónicos recientes de Rubielos de la Cérida (Teruel). Actas VI Reunión Nacional Grupo Español de Trabajo del Cuaternario, Santiago de Compostela, Vigo: 449-459.

Hanson, K.L., Kelson, K.I., Angell, M.A., Lettis, W.R (eds.) 1999. Techniques for identifying faults and determining their origins. U.S. Nuclear Regulatory Commission. Contract report NUREG/CR5503, plus appendices. Washington: $186 \mathrm{p}$.

Hernández, A., Olivé, A., Sdzuy, K., Kolb, S., Moissenet, E., Carls, P. (1983): Hoja geológica num. 465 (Daroca). Memoria y Mapa Geológico de España, E: 1:50.000. I.G.M.E., Madrid.

Jiménez, MJ., Giardini, D., Grünthal, G. (2003): The ESC-SESAME Unified Hazard Model for the European-Mediterranean region. Centre Sismologique Euro-Méditerranéen / European-Mediterranean Seismological Centre (CSEM/EMSC) Newsletter 19, 2-4.

Jiménez, MJ., Giardini, D., Grünthal, G., SESAME Working Group (2001): Unified seismic hazard modelling throughout the Mediterranean Region. Bollettino di Geofisica Teorica ed Applicata 42(12), 3-18.

Julivert, M. (1954): Observaciones sobre la tectónica de la Depresión de Calatayud. Arrahona. Publicaciones del Museo de Sabadell: 18 p.

Lafuente, P., Lamelas, T., Soriano, M.A. (2008a): Caracterización morfotectónica de la actividad de la falla de Concud (Cordillera Ibérica, Teruel). Geo-Temas 10, 1027-1030.

Lafuente, P., Arlegui, L.E., Liesa, C., Simón, J.L. (2010a): Nuevo 
estudio paleosismológico en el sector central de la Falla de Concud (Fosa del Jiloca, Teruel): Resultados preliminares. In: J.M. InsuaArévalo, F.Martín-González (eds.), Contribución de la Geología al análsis de la peligrosidad sísmica. First Iberian Meeting on Active Faults and Paleoseismology. Sigüenza: 67-70.

Lafuente, P., Arlegui, L.E., Liesa, C.L., Simón, J.L. (2010b): Paleoseismological analysis of an intraplate extensional structure: the Concud fault (Iberian Chain, Eastern Spain). International Journal of Earth Sciences. doi: 10.1007/s00531-010-0542-1

Lafuente, P., Arlegui, L.E., Liesa, C.L., Simón, J.L. (2011): Reply to the discussion by F. Gutiérrez, P. Lucha, J. Guerrero, M. Gutiérrez and D. Carbonel on the article "Paleoseismological analysis of an intraplate extensional structure: the Concud fault (Iberian Chain, Eastern Spain)". International Journal of Earth Sciences 101(2), 1-7. doi: 10.1007/s00531-011-0661-4

McCalpin, J.P. (2008): Reevaluation of geologic hazards in a mountain setting. The case of the Climax 7.5' Quadrangle, Central Colorado. $33^{\text {rd }}$ International Geological Congress, Oslo: Abstract.

Mein, P., Moissenet, E., Adrover, R. (1989-1990): Biostratigraphie du Néogène supérieur du bassin de Teruel. Paleontología i Evolució 23, 121-139.

Ministerio de Fomento (2002) Real Decreto 997/2002, de 27 de septiembre, por el que se aprueba la norma de construcción sismorresistente: parte general y edificación (NCSR-02). Boletín Oficial del Estado, October 11 th $35898-35967$

Ministerio de Fomento (2003) Norma de construcción sismorresistente: parte general y edificación (NCSR-02). Con comentarios de la Subcomisión Permanente de Normas Sismorresistentes. Centro de Publicaciones del Ministerio de Fomento, Madrid (Spain): p. 94.

Moissenet, E. (1980): Relief et déformations récentes: trois transversales dans les fossés internes des chaînes ibériques orientales. Revue Géographique des Pyrénées et du Sud-Ouest 51(3), 315-344.

Moissenet, E. (1983): Aspectos de la neotectónica en la Fosa de Teruel. In: Geología de España, Vol. II. IGME, Madrid: 423-446.
Moreno, A., González-Sampériz, P., Morellón, M., Valero-Garcés, B., Fletcher, W. (2010): Northern Iberian abrupt climate change dynamics during the last glacial cycle: A view from lacustrine sediments. Quaternary Science Reviews 36, 139-153. doi: 10.1016/j. quascirev.2010.06.031

Ollier, C.D., de Graaff, L.W.S., Gutiérrez, F., Ginesu, S., Dobrowolski, R. (2006): Neotectonic mountain uplift: some further instances. New Concepts in Global Tectonics Newsletter 39, 12-22.

Roca, E., Guimerà, J. (1992): The Neogene structure of the eastern Iberian margin: structural constraints on the crustal evolution of the Valencia trough (western Mediterranenan). Tectonophysics 203, 203-218. doi: 10.1016/0040-1951(92)90224-T.

Rubio, J.C., Simón, J.L. (2007): Tectonic subsidence v. erosional lowering in a controversial intramontane depression: the Jiloca basin (Iberian Chain, Spain). Geological Magazine 144, 127-141. doi:10.1017/S0016756806002949.

Rubio, J.C., Simón, J.L., Soriano, M.A. (2007): Interacting tectonics, hydrogeology and karst processes in an intramontane basin: the Jiloca graben (NE Spain). Hydrogeology Journal 15, 1565-1576. doi: 10.1007/s10040-007-0190-0.

Simón, J.L. (1983): Tectónica y neotectónica del sistema de fosas de Teruel. Teruel 69, 21-97.

Simón, J.L., Soriano, A. (1993): La falla de Concud (Teruel): actividad cuaternaria y régimen de esfuerzos asociado. Actas de la II Reunión del Cuaternario Ibérico. I.T.G.E., Madrid: 729-737.

Simón, J.L., Rubio, J.C., Soriano, M.A. (2010): Sobre el origen de la depresión del Jiloca (Teruel, Cordillera Ibérica centro-oriental). Geogaceta 48, 183-186.

Stirling, M., Rhoades, D., Berryman, K. (2002): Comparison of earthquake scaling relations derived from data of the instrumental and preinstrumental era. Bulletin of the Seismological Society of America 92(2), 812-830. doi:10.1785/0120000221.

Wells, D.L., Coppersmith, K.J. (1994): New empirical relationships among magnitude, rupture length, rupture width, rupture area and surface displacement. Bulletin of the Seismological Society of America 84, 974-1002. 